\title{
Uploading: The Path to Transcendence or Illusionary Escapism? A Philosophical Approach
}

\author{
DAVID COBOS-SANCHIZ \\ Department of Education and Social Psichology, Universidad Pablo de Olavide, Seville 41013, Spain \\ Email: dcobos@upo.es
}

\begin{abstract}
Transcendence has always been one of the human being's greatest desires. The hope of a real world that exists after death, in which we somehow continue living, has been the subject of multiple proposals since ancient times. Today, the consideration of the beginning and end of life has ceased to be an irremovable biological examination thanks to many advances in science. In this context, in which the borders between the biological and the artificial become increasingly blurred, the most radical transhumanist philosophy looks for an absolute abstraction of organic matter through the download or 'uploading' of our mind to a computer. This is a very complex and controversial proposal, but perhaps the only viable one when faced with the futuristic hypothesis of the definitive disappearance of the human species.
\end{abstract}

Keywords: posthumanism, cyborg, technoscience, transcendence, future

\section{BY WAY OF INTRODUCTION}

Today the boundaries between the biological and the artificial are increasingly blurred. Derrida had already considered the deconstruction of human narcissism, turning to Copernicus, Darwin and Freud, in the sense that the subject no longer constitutes itself as the center of the universe, nor on the cusp of evolution and can no longer even be considered the master of himself (Peters 2020: 4-5). Now technology delves into this crisis of the ego, revealing an unprecedented plasticity of the human body, dissolving the limits between the human and the non-human (Kriman 2019: 4), forcing us to comprehensively rethink and developing a turn towards a new anthropology (Idem: 13).

In this context, transhumanism advocates the possibility of human intervention in its own evolutionary process, based on technology, that allows the possibility of making it a post-human, that is, someone who intentionally transcends his nature (Kawanishi and Lourençao 2019: 668) and thus presenting an alternative to artificial/natural binarism (Díaz-Gandasegui 2019: 2). This idea depicts a future in which all possibilities fit, from the most optimistic to the darkest (Idem: 4 ).

Of course, one of the possible scenarios for humanity is, very clearly, the overcoming of the human being itself, as it has developed in its history, with its characteristics, 
qualities and limits. In fact, transhumanists emphasize the need to achieve such overcoming through technological development (Luca, Alvarado 2019: 308). Some authors interpret that the gradual fusion of the biological and synthetic organism would only be the end result of humanity's millennial process of creating, using tools and finally identifying through them (Veljović: 610).

Of all the possibilities proposed by transhumanist philosophy, the most radical is, without a doubt, the one that seeks the absolute abstraction of organic matter, by downloading our minds onto a computer. In this article, we review transhumanism, specifically regarding its connections with the human yearning for transcendence, connecting with other previous religious and philosophical traditions and taking into account the fact that, today, this option is beginning to be taken into account, not as mere science fiction, but as a possibility - certainly remote, but ultimately, possible.

Among its most original contributions, we would like to point out our approach to the concept of mind, the analysis of consciousness as a support for the self and its structure, the consideration of the rupture that these approaches have with the most classic traditions on the essence of human being, as well as the final consideration of this possibility as a futuristic alternative to the foreseeable disappearance of the human species.

\section{TRANSCENDENCE AND IMMORTALITY: AGE-OLD YEARNING OF HUMANITY}

The Capuchin catacombs in Palermo (Italy) house and display some 8,000 mummies, many of which line the walls, comprising a truly macabre collection. However, the most astonishing moment for visitors is the mummy of Rosalía Lombardo. She died in 1920, at the age of two, and her body was embalmed by a famous doctor of the time. The preservation is so remarkable that she is known by locals as 'the sleeping beauty'. As startling as it may be, it is not an isolated case. Attempting to preserve bodies, potentially, to bring them back to life one day is a practice that dates back thousands of years. The Chinese and Egyptian traditions of treating the bodies of their emperors, using various embalming techniques, to prepare them for their passage into Eternity are well-known.

Transcendence has always been one of humanity's greatest dreams. The hope of a real world, beyond death, in which life continues in some way after the conclusion of the physical or earthly experience has taken multiple forms in different religions. As the protagonist of San Manuel Bueno, Mártir, Miguel de Unamuno's famous novel, says on religions they make the people who profess them live spiritually, insofar as they console them for having had to be born only to die (Unamuno 1984: 83). Thus, the fear of death fades to be replaced by the belief in existence in the afterlife (Lázaro 2018: 40-49). For positivism, a paradigm which from the end of the 19th century has claimed to be the sole builder of a complete science that exceeds other states of human knowledge, which it deems naive or imperfect, this idea is simply irrelevant as it cannot be measured or confirmed empirically. Regardless of whether it is irrelevant for positivists, it is a tremendously important starting point for philosophical debate that extends far back into the history of thought.

Even for the positivists, the discussion of the start and end of life has, for some time now, no longer been a fixed matter of biology, as Barreto notes (Barreto 2011: 27). If until recently it was accepted that a person became a corpse when his/her heart stopped beating, now, as a result of multiple medical advances (transplants, assisted reproduction, and so on), the boundaries are no longer so clear. 'From all these images that are removing the old frontiers between the natural and the artificial, between nature and culture, the image/figure of 
the cyborg appears. A cybernetic organism, human-machine hybrid, whose $<\ldots$. representations pose unsettling questions on how these frontiers are formed. Where is the line between machine and human?' (Barreto 2011: 28). The appearance of 'cyborgs' or new beings that mix human and machine alongside transhumanism and the posthuman man are two possibilities that are given increasingly serious consideration (Castilla 2015: 1411).

\section{FROM HUMAN TO POSTHUMAN AND BEYOND: THE PROSPECT OF UPLOADING}

Undoubtedly, the development of Information and Communication Technology has blurred the lines between the biological and the artificial. Transhumanism now proposes a transcendental, abstract, pure being, that does not need a human, organic form. The organic body is considered an impediment to postbiological life, which must be abolished (Aguilar 2012: 70). Similarly, Koval discusses possible human-machine integration in postbiological form that is endowed 'with an unprecedented physical, intellectual, and psychological capacity, self-programming, self-configurable, unlimited, and potentially immortal; a being whose abilities radically exceed those of human beings, to the extent that it would no longer belong to the human species as currently defined by humanity' (Koval 2011: 12). The same author notes that between the most extreme positions of transhumanist philosophy is a current which seeks absolute separation from organic material by means of uploading our mind to a computer. Human beings could thus achieve immortality through technology (Popescu, Scarlat 2018: 50-56).

For Marín, this posthumanist approach is a clear exponent of the Faustian tradition. Human beings would definitively end nature's resistance. They would no longer be content to bend it to their will, rather 'they would embark on the search for and definitive conquest of their next and final frontier: the human body. The Faustian man seizes the machine, his favourite creation, to merge with it in the search for a being superior to biology' (Marín 2012: 38).

This new faith in uploading (or transfer of the mind) is connected to the desire for transcendence mentioned above and helps human beings to face the atavistic fear of death as, once the mind is transferred to another medium, we would theoretically be immortal (Seung 2012). When this uploading of our mind to a machine is mentioned, the first thing we think of is our knowledge and thoughts, in other words, the 'content' (to borrow an expression from the field of computing). Here, we are confronted by the first limitation, because most of the information contained in our brain is subconscious (Kaku 2014).

We stubbornly believe that we are an ego that is in full control of our actions and thoughts and that we always make conscious and thought-through decisions, but that is pure fiction. Our mind is, in fact, comprised of a vast number of unconscious events that occur simultaneously throughout the brain. It is only when one event overcomes the others, when our brain rationalises the result that the feeling of a single conscious self that was in control of the situation from the start materialises (Kaku 2014).

Accordingly, we would need to scan our entire content (the conscious and subconscious elements) and also the medium (or hardware, to continue the computing analogy), in other words, the neural connections in their entirety. In this task, finding what has been termed the 'connectome' of the brain would be a necessity. For Seung (2012), this connectome is defined as the totality of neural connections in a nervous system that slowly change as we learn and grow.

For an idea of the magnitude of the project, some figures are illustrative: a brain contains approximately $10^{12}$ neurons (one followed by twelve zeros). If every neuron was of a similar size to a small seed, an industrial estate with several ships and more than one hundred lorries 
and trailers would be required to transport them (García de Molina 2015: 33). Furthermore, the total information contained in a person's brain would be the equivalent of approximately all the information currently held on the internet.

These figures quickly reveal that the project is unviable with current technology. However, one can infer that it is an engineering problem, not an issue with the concept or the laws of physics. Therefore, it may become a reality in the future. Steps are currently being taken in that direction in the Brain and Human Connectome projects, which are studying the structure of the brain and mapping it via reverse engineering (see, for example, Glaseer in Nature 2016). Put another way, it will be a long time until we can scan a human brain, capture all its most important details, and place them on a computing substrate. Yet, all the signs are that this will be possible at some point, as Kurzweil predicts (Kurzweil 2005).

In fact, the most optimistic proponents believe that continuing technological development, which is advancing exponentially, will be able to deliver it much sooner than one could imagine with today's technology. The precedent of the human genome project that was initially expected to take fifteen years but, due to the development and utilisation of new and improved research techniques over the course of its development, was able to produce a practically complete genome sequence in just ten years lends support to this idea.

Despite everything, our view is that we still do not possess the full picture. Although we have the structure, the connections and the contents, we are still lacking our own highly specific software. In other words, once we have the full map of the brain (its neurons and connections) and all the contents of our mind (conscious and unconscious memory), we would still have to transfer our behaviour, our own particular way of organising those contents in reaction to situations; in short, our personality. Expressed differently, when we fully know all the parts of the system, we will also know how these parts are organised between themselves.

This point provides scope for an intense debate on free will or the unpredictability of human behaviour. However, we understand that, although extremely complex, possible reactions to every situation are not infinite. For each situation, there may be millions of possible reactions (n possibilities) but not infinite possibilities. Accordingly, by processing an enormous amount of information (using big data) our reaction could be reasonably accurately predicted. For that reason, it would be possible to create algorithms that represent our behaviour and, in short, our personality, or, at the very least, its reasonable resemblance.

Let us suppose that we already have a scan of all the content of our memory, the map of all our brain connections, and the algorithms that represent our personality. If we transfer all this to a machine, we would be 'uploading' our mind to that machine. However, as Seung (2012) notes, even if the transfer was a complete success, we could not know if that process had produced an automaton as there is no objective way of measuring the subjective feelings that we call consciousness.

\section{CONSCIOUSNESS AS A MEDIUM FOR THE EGO}

Discussing consciousness involves confronting a concept that, even today, is still being defined because it is highly complex and because its neurobiological base is also associated with a large number of structures (Yubero 2015: 87-88). According to Montserrat, it is all a result of the fact that we 'detect' our own psychic experience (Montserrat 2015: 1428). For Kaku (2014), there are various levels of consciousness in which the characterising element of human consciousness is the ability to simulate the future and, following this line, self-consciousness is the creation of a model of the world and the simulation of the future in which 
the subjects themselves appear. According to the same author, there is likely a specific part of the brain whose function is to create a feeling of a continuous and coherent self and, in agreement with Prof. Carl Zimmer, places it in the medial prefrontal cortex.

Dr. Cabanillas previously suggested, in the Informational Theory of Personality, that all the information provided to human beings by society through its institutions and other human beings is codified in the neocortex and gradually shapes consciousness (Perales 2011: 57). In the opinion of Alegre and Zumaeta, consciousness is the name given to the totality of the types of psychic information codified in the cerebral cortex; in short, consciousness is material and it has, like all material, a structure and activity (Alegre, Zumaeta 2015: 282).

This statement may upset some religious believers who identify consciousness with the soul but this is not necessarily the case in the major monotheistic religions, especially in Christianity. As Stevenson says, the interpretation that Christian doctrine recognises a dualism between material body and soul or mind is completely mistaken. Such a dualism does not appear in the Old or New Testament and is, in fact, an idea from Greek philosophy (Stevenson 1995: 62).

In any case, if consciousness is material, we can emulate its structure and function in a machine and when the machine becomes capable of creating simulations of the future in which it appears as an actor, it will have reached a higher level of consciousness, similar to that of humans. It is interesting to note at this point that there is a break with the classical tradition regarding the definition of human essence. Aristotle had taught us that the voice, as a sign of pain and pleasure, is also possessed by animals but that it is the word, which can manifest the just and the unjust, which makes us truly human as zoon logon echon (Karmi 2006: 2). However, it is precisely from the deployment of technical domains that the potentialities are born, which we will later define as properly human. Language is, in fact, one of those dimensions that emerges as a technical activity and that, through a deployment of millions of years, structurally shapes a body. Understood in this way, we have always been drifting cyborgs (Maureira-Velásquez 2019: 5).

The attempt to understand and define the essence of the human versus the animal is a constant in the history of western philosophy, in which numerous authors have pointed out different aspects such as speech, thought, reason, laughter, work, or creation as differentiating elements. In our view, however, we have long since understood that the human species is not the only intelligent species, but rather that which is the most intelligent among all those in the animal kingdom.

In the same sense, we can infer that the human being is not the only species with self-awareness, but rather the species that has the most perfected level of those known. There is nothing preventing us, however, once we understand their mechanisms, from emulating them (and maybe perfecting them) using a machine. The posthumanist conception thus transcends the idea of the human as being 'ontologically closed', defined and definable, and goes beyond the traditional idea of form (Valera 2014: 482-485).

From a more intuitive perspective, one can return to the quote from the psychiatrist Giulio Tononi, mentioned by Kaku (2014) who summaries consciousness as that which leaves us every night when we fall into a deep sleep and returns to us the following morning when we awaken. In this sense, the sensation of deep sleep is the closest experience to death we can have whilst alive. Neurobiologists and psychologists would argue that brain activity is, in fact, tremendously intensive whilst sleeping and that we are equally 'alive' whether we are awake or asleep. 
This is obviously true but it is also the case that we possess self-consciousness when we are awake and we lose it whilst in deep sleep. Every night we experience the sensation of 'dying' psychically from the perspective of self-consciousness. We rehearse death, so to speak, as we completely disconnect from conscious reality and, likewise, every morning we 'revive' our ego, when our alarm clock sounds and we begin our daily routine.

Obviously, I look at myself in the mirror, I recognise myself, I am unmistakably myself, the same person who fell asleep last night and today faces a new day. Yet, what if technology today made uploading possible? How could I know that me was exactly the same as the one who fell asleep yesterday and has woken up today or am I a different being (different vessel) which has been given all my memory, connections and algorithms? If this being has all my memories and my emotions (or appearance of emotions), the basic traits of my personality and behaviour (in short, all my information and the way I usually link it) and, above all, 'remembers' being me, is not it me? Because who am I, really?

Kurzweil (2005) offers the following reflection on the issue. If I am the chaotic collection of molecules that make up my body and mind, that specific combination of particles is really completely different to the atoms and molecules of which it was composed just a short time ago. We are in constant change. Cells appear and die continuously and our brain permanently establishes new and different connections as a result of, amongst other factors, learning.

This assessment is linked to the Ship of Theseus paradox, as related by Plutarch. In this legend, Theseus was the captain of a ship that had been preserved since the time of Demetrius by constantly replacing and repairing the oldest and most worn planks over the centuries. After years of repairs and replacements, could this ship be considered the same one as Demetrius' or was it a different one? Similarly, if all our cells are systematically replaced after a certain period of time (even neurons change atoms and molecules periodically), are we the same person now as twenty years ago or are we a different person?

Kurzweil posits that perhaps we should conclude that our ego is a template of material and energy that persists over time. It is this template that we will eventually be able to upload to a machine to replicate ourselves in such a way that the copy will be indistinguishable from the original. The same author continues to hold that, even though the copy may share our template, even though it has all our memories and remembers being me, from the moment it is created it would start to have its own experiences and its reality would start to differ from mine. In other words, it would be the same as me at the start but it would not be me. This argument, nevertheless, in our opinion may lead to other conclusions.

As we have stated, our ego is a template that persists over time and also an illusion created by the brain itself to ensure the conscious coherence of this template. The template constantly changes and reshapes through learning. Obviously, if we upload while we are alive we will get an identical copy of me at first, that is alive alongside me, that lives with me, and, as perfect as the copy may be, it would start to acquire, through its own different experiences and learning, a very similar but ultimately different personality to mine. In short, we would have created something akin to a human twin.

But if we make the transition to the machine progressive and gradual or if we press the 'on' button when we are deceased, there will not be a twin that lives alongside me, there will be a unique being that when it wakes up that morning, it will remember that it is me, has my personality template, and starts from that moment onwards to have every type of random and chaotic learning experiences, just as I would have. Accordingly, its personality 
would constantly evolve through experience from that point onwards, just as one can say that we, once reset and refreshed by deep sleep, press our own 'on' button every morning. What is the difference?

If this technology already existed, I would find it impossible to know if the person in the mirror is the same one that went to sleep the night before or a different recently activated being (my mind in a new vessel). In both cases, I would remember being me and act according to my templates. Let us consider it again. When I fall asleep once again tonight, from the perspective of my self-consciousness I will be rehearsing my own death. When I wake up (tomorrow morning or in a thousand years), I will bring it back to life seamlessly. I will not be able to remember if I have slept for just one night or a thousand years. Some circuits (neurons or chips) will simply start to operate which will reactivate my awareness of my ego with the memories that had been acquired up to that point. From that very moment, the construction of new thoughts, learning, memories, and personality differences would start in my mind (whether biological or silicon-based) as I set out on a new day that morning.

\section{IN CONCLUSION}

For Montserrat, the proposal of creating a mind in a machine is a false perspective because the computer cannot ontologically or functionally create a mind. In knowledge engineering terms, it can only simulate one (Montserrat 2015: 1438). Montserrat thinks that whilst machines function by means of mechanical, blind processes, human reasoning functions by means of the combination and analysis of sensitive images that form the essence of the mind and the consciousness of the ego as a psychic subject. The foundation of this argument is that the functions, processes and states of this reasoning are biological (psycho-bio-physical).

However, other authors differ. For Bostrom, provided that it does not affect functionality or consciousness, the substrate is morally irrelevant. From a moral perspective, it is of no importance whether someone functions on silicon or biological neurons (in the same way that skin colour is of no importance) (Kurzweil, 2005). If we strive for a Humanity free from racism, for nobody to be discriminated against based on their sex, social circumstances, or political or religious beliefs, then why should we now be racist or discriminate against individuals whose consciousness is built on silicon or any other material?

Bostrom and Kurzweil's hypothesis is that it will be possible to create a mind in a machine. Whilst Montserrat asserts that it would be possible to create a simulation but not a human mind ('strong metaphor' versus 'weak metaphor', in the author's own words) (Montserrat 2015: 1420). Let us add a third way or 'possibilist metaphor': the only real way for a human mind (in its entirety or as a very successful recreation) to persist over time is by a change in medium.

Whether we like it or not, our brain (the main medium of consciousness), although more complex than the universe itself, is highly fragile, is small (in size), is limited (it cannot expand), and is mortal (García de Molina 2015: 34). Ultimately, when speaking in general terms of body transplants, biological resuscitations using procedures such as cryonics, or the colonisation of other planets, we are simply postponing modestly and temporarily an ending that today seems inevitable: the final disappearance of the human species. 


\section{References}

1. Aguilar, T. 2012. Ontología Cyborg. El cuerpo en la nueva sociedad tecnológica. Barcelona: Gedisa.

2. Alegre, A. A.; Zumaeta, P. A. 2015. 'La relación mente-cerebro: Una propuesta de solución basada en formas de neguentropía intra y extra individuales', Propósitos y Representaciones 3(1): 265-311. Available at: https://revistas.usil.edu.pe/index.php/pyr/article/view/73

3. Barreto, C. M. 2011. 'Transgresiones corporales, rituales de belleza y seres poshumanos', Atlántida 3: 17-34.

4. Castilla, A. 2015. 'La Séptima Gran Cosmovisión: Mecánica Cuántica y Universo Consciente', Pensamiento 71(269): 1401-1415.

5. Díaz-Gandasegui, V. 2019. 'El amor en tiempo de posthumanismo', Athenea Digital 19(1): e2231. Available at: https://revistas.upcomillas.es/index.php/pensamiento/article/view/6591

6. García de Molina, M. 2015. 'Universo, cerebro y resurrección', Cuenta y Razón 34: 33-40.

7. Glaseer, M. F.; Coalson, T. S.; Robinson, E. C.; Hacker, C. D.; Harwell, J.; Yacoub, E.; Ugurbil, K.; Andersson, J.; Beckmann, C. F.; Jenkinson, M.; Smith, S. M.; Van Essen, D. C. 2016. 'A Multi-modal Parcellation of Human Cerebral Cortex', Nature 536(7615): 171-178.

8. Kaku, M. 2014. The Future of the Mind. New York: Doubleday.

9. Karmi, R. 2006. 'Sobre la "decisión" en la prudencia de Aristóteles (una introducción al problema de lo animal y lo humano)', A Parte Rei: revista de filosofía 46: 1-16. Available at: https://serbal.pntic.mec. es/ cmunoz11/karmy46.pdf

10. Kawanishi, P.; Lourençao, G. 2019. 'Humanos que queremos ser. Humanismo, Ciborguismo e PósHumanismo como Tecnologias de Si', Trabalhos en Linguística Aplicada 58(2): 658-678.

11. Koval, S. 2011. 'Convergencias tecnológicas en la era de la integración hombre-máquina', Razón y palabra 75: 1-17. Available at: https://www.redalyc.org/pdf/1995/199518706043.pdf

12. Kriman, A. I. 2019. 'The Idea of the Posthuman: A Comparative Analysis of Transhumanism and Posthumanism', Russian Journal of Philosophical Sciences = Filosofskie nauki 62(4): 132-147.

13. Kurzweil, R. 2005. The Singularity is Near. When Humans Transcend Biology. New York: Viking Books.

14. Lázaro, C. 2018. 'El fenómeno de las experiencias cercanas a la muerte (ECM)', Fronteras de la Ciencia 3: 40-49.

15. Luca, J. T.; Alvarado, T. 2019. 'Posthumanismo e hibridación', Pensamiento 75(283): 307-319.

16. Marín, R. F. 2012. 'Ser o no ser [Cyborg] tecnología y cultura: de la tradición prometeica a la tradición fáustica', Trilogía 7: 33-58. Available at: https://revistas.itm.edu.co/index.php/trilogia/article/view/152

17. Maureira-Velásquez, M. 2019. 'Una metafísica de la vida: contra el posthumanismo y el nuevo materialismo', Digithum 23: 1-13. Available at: https://revistas.itm.edu.co/index.php/trilogia/article/ view/152

18. Monserrat, J. 2015. 'El transhumanismo de Ray Kurzweil. ¿Es la ontología biológica reductible a la computación?', Pensamiento 71(269): 1417-1441. Available at: https://revistas.upcomillas.es/index.php/pensamiento/article/view/6592

19. Perales, A. 2011. 'Dr. Pedro Ortiz Cabanillas', Acta Médica Peruana 28(1): 56-57.

20. Peters, M. A. 2020. 'Posthumanism, platform ontologies and the "wounds of modern subjectivity", Educational Philosophy and Theory 52(6): 579-585.

21. Popescu, F.; Scarlat, C. 2018. ‘¿Resulta posible una inmortalidad digital?', Fronteras de la Ciencia 3: 50-56.

22. Seung, S. 2012. Connectome: How the Brain's Wiring Makes Us Who We Are. Boston: Houghton Mifflin Harcourt.

23. Stevenson, L. 1995. Siete teorías de la naturaleza humana. Madrid: Cátedra.

24. Unamuno, M. 1984. San Manuel Bueno, mártir. Madrid: Castalia.

25. Valera, L. 2014. 'Post-Humanism: Still or Beyond Humanism', Cuadernos de Bioética 25(3): 481-491.

26. Veljović, J. A. 2019. 'Posthumanizam kao modus problematizacije i nadogradnje humanizma', Issues in Ethnology and Anthropology 14(2): 607-626.

27. Yubero, R. 2015. 'Bases neurobiológicas de la conciencia’, Cuenta y Razón 34: 87-90. 
DAVID COBOS-SANCHIZ

\title{
Ilkẻlimas: kelias ị transcendenciją ar iliuziškas eskapizmas? Filosofinis požiūris
}

\begin{abstract}
Santrauka
Transcendencija visada buvo vienas didžiausių žmogaus troškimų. Visais laikais buvo puoselëjama viltis dèl tikro pasaulio, egzistuojančio po mirties, kuriame kažkaip ir toliau gyvensime. Šiandien gyvenimo pradžios ir pabaigos svarstymas dèl daugybès mokslo pasiekimų liovèsi buvęs tik biologiniu tyrinèjimų objektu. Vis labiau išsiplauna riba tarp to, kas biologiška, ir to, kas dirbtina, pati radikaliausia transhumanistinè filosofija ieško organinès materijos absoliučios abstrakcijos parsisiunčiant arba „ikeliant“ mūsų protą i kompiuterị. Tai labai kompleksiškas ir kontroversiškas pasiūlymas, tačiau galbūt jis vienintelis gyvybingas susidūrus su galutinio žmonių rūšies išnykimo futuristine hipoteze.
\end{abstract}

Raktažodžiai: posthumanizmas, kyborgas, technomokslas, transcendencija, ateitis 